\title{
Metal Pollution Indices of Surface Sediment and Water from the Upper Reaches of Sombriero River, Niger Delta, Nigeria
}

\author{
Ibigoni Clinton Howard ${ }^{1 *}$ and Briggs Amonia Olulu ${ }^{2}$ \\ ${ }^{1}$ Department of Chemistry/Biochemistry Federal Polytechnic, Nekede, Owerri. Imo State, Nigeria \\ ${ }^{2}$ Department of Chemistry, Rivers State University of Science and Technology Port Harcourt. \\ Rivers State Nigeria \\ *E-mail: dromiete_ib@yahoo.com
}

\begin{abstract}
Metal pollution indices of the surface sediments and water of the upper reaches of Sombriero river was investigated using Absorption Spectrophotometery. The data obtained for the metals- $\mathrm{Cd}, \mathrm{Pb}, \mathrm{V}, \mathrm{Fe}, \mathrm{Ni}, \mathrm{Cu}$ and $\mathrm{Zn}$ showed consistency in the metal pollution indices of the various stations of the study area. The stations with higher pollution indices were related to areas of intense activities. Several metal pair correlations were obtained in the surface sediments than in the surface water. Both media had $\mathrm{Zn}-\mathrm{Cd}$ and $\mathrm{Cu}-\mathrm{Fe}$ metal pair correlations. The pattern of the metals in the surface water at $95 \%$ significant level is $\mathrm{Fe}>\mathrm{Zn}=\mathrm{Cu}=\mathrm{Pb}=\mathrm{N}=\mathrm{Cd}=\mathrm{V}$ while that of the sediment is $\mathrm{Fe}>\mathrm{Zn}=\mathrm{Cu}=\mathrm{Ni}=\mathrm{Pb}=\mathrm{V}=\mathrm{Cd}$. Each of the metals differed significantly between the media $(\mathrm{P}<0.05)$ sediment $>$ water, indicating the former to be a better monitoring index of aquatic pollution by these metals. In comparison to other related work the degree of contamination of the upper reaches of the Sombriero River is low but a gradual enrichment of these pollutants could have a deleterious effect on the aquatic resources of the area and the consumers thereof.
\end{abstract}

Key words: Pollution indices, sediment, water, Sombriero river, Niger Delta

\section{Introduction}

Heavy metals can be present in amounts several times higher than their natural background levels and pollute marine sediments and water in coastal regions near industries and urban areas (Andrade et al., 2001; Masoud et al., 2005). The aquatic ecosystem is frequently the ultimate recipient of heavy metal pollution from various sources-industrial wastewater, urban surface water runoff, accidental discharges into the aquatic environment through exploration and exploitation of natural resources, geological formation and weathering, agricultural practices etc (Biney et al., 1994; Masoud et al., 2005; Gupta et al., 2009). Heavy metal concentration in the water column can be relatively low in some cases, but the concentrations in the sediment may be elevated (Stanton et al., 1983; Shukla and Sharma, 2009). Weis et al. (1992) have indicated that due to temporal and spatial variability in water column, it is always problematic to obtain representative samples to actually show the true concentration of contaminants in surface water. On the other hand sediments integrate contaminants over time and are in constant flux with the overlaying water 
Ibigoni Clinton Howard and Briggs Amonia Olulu/ Our Nature (2012) 10: 206-216

column, hence the analysis of heavy metals in sediments permits detection of contaminants that may be either absent or having low concentrations in the water column (Davies et al., 1991; Shukla and Sharma, 2009).

Low level discharges of a contaminant may meet the water quality criteria, but long-term partitioning to the sediments could result in the accumulation of high loads of pollutants (Martine and Whitfield, 1983) thereby constituting environmental hazards to the urban and rural population that depend on these for various purposes. Once heavy metals are discharged into coastal waters, they rapidly become associated with particulates and are incorporated in the organic matter of the sediment which influence the adsorption of metallic elements (Jackson, 1998; Agirtas and Kilice, 1999; Goodwin et al., 2003)

Aquatic microflora and microfauna, which constitute fish food, are capable of incorporating and accumulating heavy metals into their living cells from their environment. Consequently, small fish become enriched with the accumulated heavy metals. Predatory fish generally display higher levels of heavy metals than their prey and eventually man on consuming the predatory fish suffers from the results of an enrichment having taken place at each trophic level (Forstner and Wittman, 1983; Agah et al., 2009).

River Sombrieo is one of the major rivers in the Niger delta that interconnects lots of communities and where major transportation, fishing, agricultural practices, exploration and exploitation of crude oil are being carried out. Besides, the economic life of the communities along the river depends mainly on the creeks and mangrove mudflats of the river from where they fetch finfish, shellfish and wood.

\section{Materials and methods}

Five sampling stations (SSA, SSB, SSC, SSD and SSE) hereafter referred to as A, B, $\mathrm{C}, \mathrm{D}$ and $\mathrm{E}$ were chosen within the study area as indicated in figure 1. Sample station A lies within Longtitude $6^{\circ} 45^{\prime} 21.8^{\prime \prime} \mathrm{E}$ and Latitude $4^{\circ} 45^{\prime} 38.8^{\prime \prime} \mathrm{N}$ which is the upper most part of Sombrieor River and towards the lower reaches of Orashi River. The major activity in this station is marine transport with outboard petrol engines and also the fermentation of cassava for the production of "fufu"-a familiar food in Southern Nigeria. Station B $\left(6^{\circ} 46^{\prime} 21.1^{\prime \prime} E\right.$ and $4^{\circ} 41^{\prime} 32.7^{\prime \prime} \mathrm{N}$ ) has a pipeline manifold that transports crude oil or condensate to Soku Gas Gathering Plant. This station receives the bulk of discharge of waste water runoff from domestic and municipal activities in the near by communities (Krakrama, Obonoma, Degema, Abonnema etc). Domestic and industrial wastes from Soku and the Gas Gathering Plant also release much waste to this station, in addition to the heavy marine transportation activities. Station C ( $6^{\circ} 46^{\prime} 51.5^{\prime \prime} \mathrm{E}$ and $4^{\circ} 40$ $29.6^{\prime \prime} \mathrm{N}$ ) was at a fishing settlement, a fast growing settlement where several activities, such as crude oil, diesel and petrol bunkering take place. Station D $\left(6^{\circ} 48\right.$ $14.0^{\prime \prime} \mathrm{E}$ and $4^{\circ} 38^{\prime} 23.5^{\prime \prime} \mathrm{N}$ ) was at the Idama oil Field, operated by one of the major oil companies in Nigeria. There is a flow station (wherein petroleum fluid is partially treated), wellheads and a manifold. There are dredge-spoils and waste pits with flare points, where hydrocarbons and associated emissions are discharged and waste fuels are burnt. Station E $\left(6.49^{\circ} 10.0^{\prime} \mathrm{E}\right.$ and $4.38^{\circ}$ 
Ibigoni Clinton Howard and Briggs Amonia Olulu/ Our Nature (2012) 10: 206-216

$33.9^{\prime} \mathrm{N}$ ) was also a fishing settlement where bunkering activities also takes place. Barges and tug-boats ply an adjourning creek to the New Calabar River.

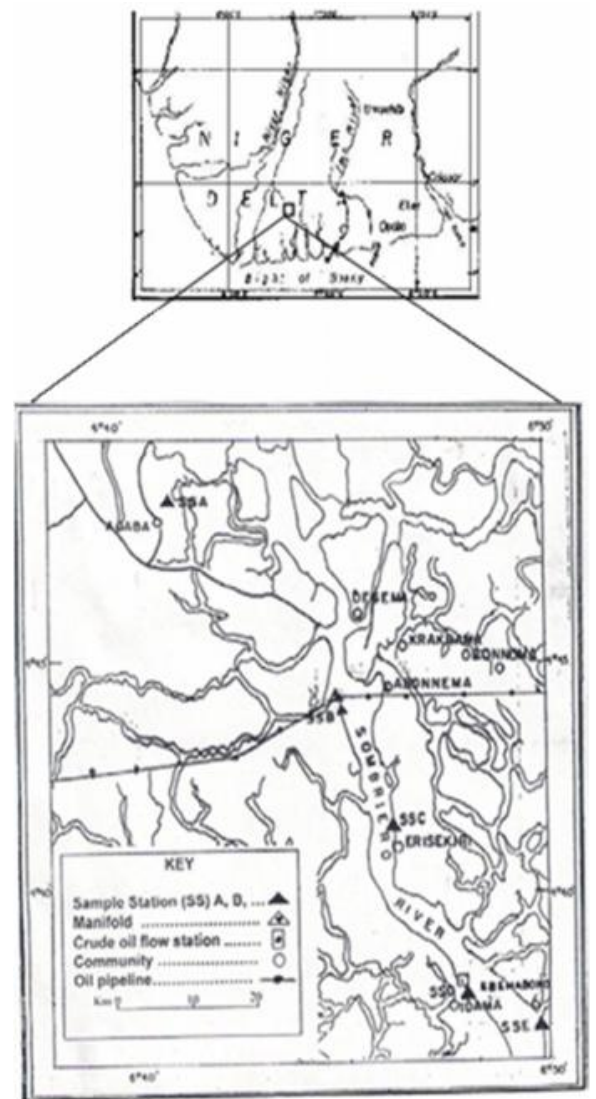

Figure 1. Map of the study area.

The oxidised surface layers of sediment, which interact most readily with overlaying water were grabbed and two liters of surface water samples were collected at three sites in each of the stations, quarterly between August 2006 and July 2007 at the five sampling stations in the study area (Fig. 1) into polyethylene cans. Water samples were acidified to $\mathrm{pH}$ of 1.5 with nitric acid (APHA, 1995).

Samples were properly labelled and taken to the Institute of Pollution Studies
Laboratory, Rivers State University of Science and Technology, Port Harcourt. Sediment samples were air dried at $40^{\circ} \mathrm{C}$ for 48hours and sieved with a $1.0 \mathrm{~mm}$ US standard sieve. $0.5 \mathrm{~g}$ each of the samples was digested by the nitirc acid-perchloric acid method described by Adams et al. (1980), while the water samples were treated after the method of Okafor and Opuene (2007). Aliquot portions were analysed for the heavy metals with Atomic Absorption Spectrophotometer Buck Scientific 200A. At all stages from sampling to the final determination point care was taken to avoid contamination of samples and to minimise loss of analyte by adsorption onto the walls of the containers. All reagents used were of AnalaR grade and all glassware and polyethylene were properly cleaned with acid-cleansing reagents and rinsed thoroughly with distilled deminerized water.

\section{Metal pollution index}

To compare the total content of metals at the different sampling stations, the Metal Pollution Index (MPI) was used. The MPI was obtained with the equation: $\mathrm{MPI}=\left(\mathrm{Cf}_{1}\right.$ $\left.\mathrm{X} \mathrm{Cf}_{2} \ldots \ldots \ldots \mathrm{Cf}_{\mathrm{K}}\right)^{1 / \mathrm{K}}$,

Where; $\quad \mathrm{Cf}_{1}=$ concentration value of the first metal.

$\mathrm{Cf}_{2}=$ concentration value of the second metal.

$$
\mathrm{Cf}_{\mathrm{k}}=\text { concentration value of the } \mathrm{kth}
$$
metal.

\section{Partition coefficient}

The level of partitioning of the metals between the surface water and sediments of the area (Partition coefficients $\left.\left(\mathrm{K}_{\mathrm{d}}\right)\right]$ was calculated using the following relation (Masoud et al., 2005). 
Ibigoni Clinton Howard and Briggs Amonia Olulu / Our Nature (2012) 10: 206-216

The $K_{d}$ was transformed into natural logarithm form to ascertain the medium that concentrates the metal more.

$$
\mathrm{K}_{\mathrm{d}}=\frac{\left[\text { Metal }_{\text {sediment }}\right.}{[\text { Metal }]_{\text {water }}}
$$

\section{Correlation coefficient}

The correlation coefficients of the various metal pairs were calculated with the aid of Pearson product moment coefficient to show the association of the metal pairs in each medium.

\section{Coefficient determination}

The determination coefficient $\left(\mathrm{r}^{2}\right)$ of each of the metal was carried out by regressing the values of one medium on the other to establish a functional relationship of how each of the metals will respond to a unit change in any of the medium.

\section{Statistical analysis}

All statistical analysis was carried out with the aid of Data Analysis Toolpak in Microsoft office Excell $2003^{\odot}$ and SPSS. Differences in the levels of the metals within and between the media were separated by Duncan Multiple range test (DMRT) at 95\% level of significance (Wahua, 1999).

\section{Results}

The mean levels of the metals $\mathrm{Cd}, \mathrm{Pb}, \mathrm{V}$, $\mathrm{Fe}, \mathrm{Ni}, \mathrm{Cu}$ and $\mathrm{Zn}$ in the surface sediments and water of the tidal flats of Sombriero river as presented in table 1 indicated $\mathrm{Fe}$ to be the highest in both media and $\mathrm{Cd}$ the least in the sediment, while $\mathrm{V}$ is the least in surface water. Each of the metal differed significantly between the media $(\mathrm{P}<0.05)$ sediment $>$ water (Tab. 1). The pattern of the metals in the surface water at $95 \%$ significant level is $\mathrm{Fe}>\mathrm{Zn}=\mathrm{Cu}=\mathrm{Pb}=\mathrm{N}=$ $\mathrm{Cd}=\mathrm{V}$ while that of the sediment is $\mathrm{Fe}>\mathrm{Zn}$ $=\mathrm{Cu}=\mathrm{Ni}=\mathrm{Pb}=\mathrm{V}=\mathrm{Cd}$. Although there were no significant differences $(\mathrm{P}>1)$ of the metal pollution indices between the various stations the pattern of the metal levels in all the stations studied followed $\mathrm{B}>\mathrm{D}>\mathrm{C}>\mathrm{A}>\mathrm{E}$ for surface water (Fig. 2) and $A>B>E>D>C$ for sediments (Fig. 3).

The regression analysis of the metals between both media showed some positive $(\mathrm{Cd}, \mathrm{V}, \mathrm{Fe}, \mathrm{Zn})$ and negative $(\mathrm{Pb}, \mathrm{Ni}, \mathrm{Cu})$ linear relationships (Tab. 2). $\mathrm{Zn}$ had the strongest relationship between both media $(\mathrm{r}$ $=0.341)$ and was closely followed by $\mathrm{Pb}(\mathrm{r}$ $=0.335)$ and $\mathrm{Cd}(\mathrm{r}=0.331)$. The determination coefficient $\left(r^{2}\right)$ of the metals between the sediment and water indicated $\mathrm{Zn}$ (11.6\%) and $\mathrm{Cd}(11.2 \%)$ to be more dependable to each of the medium than in the other metals. V had the highest log transformed partition coefficient and was followed by $\mathrm{Fe}$ while the least was $\mathrm{Cd}$ ( Tab. 2 ). The Pearson product moment correlation coefficients of heavy metals in both media showed several metal pair correlations $(\mathrm{P}<0.05)$ (Tab. 3). Surface sediments had more correlations than the surface water. Both media have these metal $\mathrm{Zn}-\mathrm{Cd}$ and $\mathrm{Cu}-$ Fe pair correlations.

\section{Discussion}

Surface Sediment and water pollution is considered by many regulatory agencies to be one of the largest risks to the aquatic environment since many aquatic organisms spend the major portion of their lifecycle living on or in sediments. For the seven metals studied in the surface sediments and water $(\mathrm{Cd}, \mathrm{Pb}, \mathrm{V} \mathrm{Fe}, \mathrm{Ni}, \mathrm{Cu}$ and $\mathrm{Zn})$, significant differences were not established among stations means. This may be due to the continuous dilution of the water body 
Ibigoni Clinton Howard and Briggs Amonia Olulu / Our Nature (2012) 10: 206-216

Table 1. Mean values of the metals form the various stations in the two media.

\begin{tabular}{|c|c|c|c|c|c|c|c|}
\hline \multirow[b]{2}{*}{ Media } & \multirow[b]{2}{*}{ Metal } & \multicolumn{5}{|c|}{ Stations } & \multirow{2}{*}{$\begin{array}{l}\text { Total } \\
\text { Mean }\end{array}$} \\
\hline & & $\mathbf{A}$ & B & C & D & $\mathbf{E}$ & \\
\hline \multirow{7}{*}{$\begin{array}{l}\text { Surface } \\
\text { water } \\
(\mathrm{mg} / \mathrm{l})\end{array}$} & Cd & $0.048 \pm 0.011^{\mathrm{a}}$ & $0.061 \pm 0.009^{\mathrm{a}}$ & $0.040 \pm 0.008^{\mathrm{a}}$ & $0.040 \pm 0.034^{\mathrm{a}}$ & $0.043 \pm 0.013^{\mathrm{a}}$ & $0.043 \pm 0.018^{\mathrm{B}, \mathrm{B}^{*}}$ \\
\hline & $\mathbf{P b}$ & $0.115 \pm 0.056^{\mathrm{a}}$ & $0.242 \pm 0.158^{\mathrm{a}}$ & $0.145 \pm 0.113^{\mathrm{a}}$ & $0.221 \pm 0.110^{\mathrm{a}}$ & $0.117 \pm 0.114^{\mathrm{a}}$ & $0.168 \pm 0.116^{\mathrm{B}, \mathrm{B} *}$ \\
\hline & $\mathbf{V}$ & $0.001 \pm 0.001^{\mathrm{b}}$ & $0.004 \pm 0.001^{\mathrm{b}}$ & $0.002 \pm 0.001^{\mathrm{b}}$ & $0.004 \pm 0.002^{\mathrm{a}}$ & $0.002 \pm 0.000^{\mathrm{ab}}$ & $0.003 \pm 0.001^{\mathrm{B}, \mathrm{B}^{*}}$ \\
\hline & $\mathbf{F e}$ & $1.778 \pm 0.34^{\mathrm{a}}$ & $2.470 \pm 1.12^{\mathrm{a}}$ & $2.067 \pm 0.69^{\mathrm{a}}$ & $2.809 \pm 0.81^{\mathrm{a}}$ & $1.601 \pm 0.98^{\mathrm{a}}$ & $2.145 \pm 0.867^{\mathrm{A}, \mathrm{B}^{*}}$ \\
\hline & Ni & $0.115 \pm 0.054^{\mathrm{a}}$ & $0.220 \pm 0.142^{\mathrm{a}}$ & $0.168 \pm 0.050$ & $0.165 \pm 0.094^{\mathrm{a}}$ & $0.094 \pm 0.053^{\mathrm{a}}$ & $0.152 \pm 0.089^{\mathrm{B}, \mathrm{B}^{*}}$ \\
\hline & $\mathrm{Cu}$ & $0.377 \pm 0.094^{\mathrm{bc}}$ & $0.591 \pm 0.150^{\mathrm{a}}$ & $0.391 \pm 0.075^{\mathrm{ab}}$ & $0.564 \pm 0.082^{\mathrm{ab}}$ & $0.186 \pm 0.193^{\mathrm{c}}$ & $0.422 \pm 0.188^{\mathrm{B}, \mathrm{B}^{*}}$ \\
\hline & Zn & $0.634 \pm 0.218^{\mathrm{a}}$ & $0.535 \pm 0.200^{\mathrm{a}}$ & $0.466 \pm 0.165^{\mathrm{a}}$ & $0.373 \pm 0.278^{\text {la }}$ & $0.511 \pm 0.183^{\mathrm{a}}$ & $0.504 \pm 0.208^{\mathrm{B}, \mathrm{B}^{*}}$ \\
\hline \multirow{6}{*}{$\begin{array}{l}\text { Sediments } \\
(\mu \mathrm{g} / \mathrm{g}) \\
\text { dry wt }\end{array}$} & Cd & $\begin{array}{c}4.01 \pm 2.75^{\mathrm{a}} \\
48.32 \pm 28.64^{\mathrm{a}}\end{array}$ & $\begin{array}{c}3.50 \pm 1.59^{\mathrm{a}} \\
31.81 \pm 7.47^{\mathrm{a}}\end{array}$ & $\begin{array}{c}2.30 \pm 2.45^{\mathrm{a}} \\
32.83 \pm 26.23^{\mathrm{a}}\end{array}$ & $\begin{array}{c}3.17 \pm 2.31^{\mathrm{a}} \\
18.73 \pm 11.70^{\mathrm{a}}\end{array}$ & $\begin{array}{c}2.11 \pm 1.75^{\mathrm{a}} \\
33.45 \pm 14.39^{\mathrm{a}}\end{array}$ & \\
\hline & $\mathbf{P b}$ & $\begin{array}{l}48.32 \pm 28.04 \\
10.54 \pm 3.82^{b}\end{array}$ & $11.79 \pm 6.39^{\mathrm{b}}$ & $13.84 \pm 11.39^{\mathrm{ab}}$ & $27.41 \pm 14.20^{\mathrm{a}}$ & $\begin{array}{l}33.45 \pm 14.39^{\circ} \\
16.14 \pm 6.10^{\mathrm{ab}}\end{array}$ & $33.453 \pm 14.39^{\mathrm{B}, \mathrm{A}^{*}}$ \\
\hline & $\mathrm{Fe}$ & $6914.0 \pm 1071.2^{\mathrm{a}}$ & $6954.5 \pm 1537.9^{\mathrm{a}}$ & $7543.0 \pm 2138.7^{\mathrm{a}}$ & $7524.3 \pm 1182.5^{\mathrm{a}}$ & $8495.3 \pm 1877.2^{\mathrm{a}}$ & $8495.2 \pm 1877^{\mathrm{A}, \mathrm{A}^{*}}$ \\
\hline & $\mathrm{Ni}$ & $61.66 \pm 40.06^{\mathrm{a}}$ & $69.45 \pm 41.41^{\mathrm{a}}$ & $35.27 \pm 37.58^{\mathrm{a}}$ & $41.18 \pm 27.54^{\mathrm{a}}$ & $35.53 \pm 32.09^{\mathrm{a}}$ & $48.617 \pm 35.24^{\mathrm{B}, \mathrm{A}^{*}}$ \\
\hline & $\mathrm{Cu}$ & $72.04 \pm 45.39^{\mathrm{a}}$ & $77.60 \pm 47.53^{\mathrm{a}}$ & $52.09 \pm 49.35^{\mathrm{a}}$ & $46.13 \pm 27.44^{\mathrm{a}}$ & $67.36 \pm 33.52^{\mathrm{a}}$ & $63.042 \pm 38.91^{\mathrm{B}, \mathrm{A}^{*}}$ \\
\hline & $\mathbf{Z n}$ & $93.21 \pm 52.92^{\mathrm{a}}$ & $97.67 \pm 55.55^{\mathrm{a}}$ & $61.71 \pm 47.10^{\mathrm{a}}$ & $66.57 \pm 43.01^{\mathrm{a}}$ & $77.83 \pm 25.11^{\mathrm{a}}$ & $79.398 \pm 43.39^{\mathrm{B}, \mathrm{A}^{*}}$ \\
\hline
\end{tabular}

-Within row (for each medium and metal), mean \pm std with different superscript (lower case letters) are significantly different at $\mathrm{P}<0.05 .(\mathrm{n}=20)$

-Within column (Total mean metals within a medium), mean \pm std with different superscript (upper case letters) are significantly different at $\mathrm{P}<0.05 .(\mathrm{n}=20)$

-Within column (Total mean metals between media), mean \pm std with different superscript (upper case letters*) are significantly different at $\mathrm{P}<0.05 .(\mathrm{n}=20)$

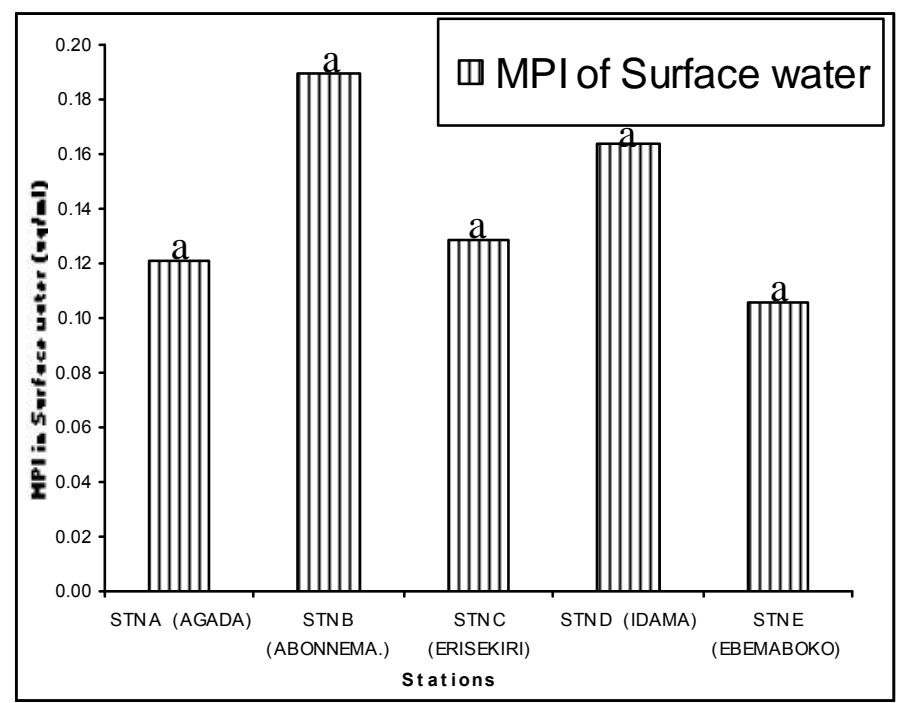

Figure 2. Surface water Metal pollution index (MPI) for each sampling station. 
Ibigoni Clinton Howard and Briggs Amonia Olulu / Our Nature (2012) 10: 206-216

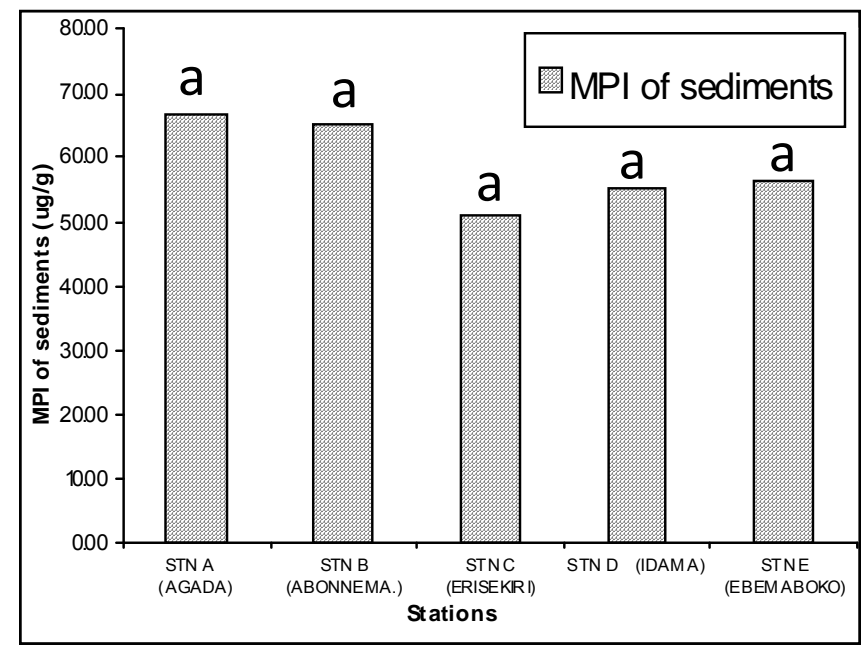

Figure 3. Sediment Metal pollution index (MPI) for each sampling station.

Table 2. Various relationships of the metals in the media.

\begin{tabular}{|l|l|c|c|c|c|}
\hline Metals & $\begin{array}{c}\text { Relationship } \\
\text { [Sediment (y) and surface } \\
\text { water (x)] }\end{array}$ & $\begin{array}{c}\text { Determination } \\
\text { coefficient }\left(\mathbf{r}^{\mathbf{2}}\right)\end{array}$ & $\begin{array}{c}\text { Correlation } \\
\text { coefficient } \\
(\mathbf{r})\end{array}$ & $\begin{array}{c}\text { Partition } \\
\text { coefficient (kd) }\end{array}$ & LogKd \\
\hline $\mathrm{Cd}$ & $\mathrm{Y}=3.904 \mathrm{x}+2.8373$ & $0.11 \%$ & 0.331 & 65.067 & 1.813 \\
\hline $\mathrm{Pb}$ & $\mathrm{Y}=-57.345 \mathrm{x}+42.664$ & $11.22 \%$ & 0.335 & 196.69 & 2.294 \\
\hline $\mathrm{V}$ & $\mathrm{Y}=218.856 \mathrm{x}+15.409$ & $0.10 \%$ & 0.032 & 6495.7 & 3.813 \\
\hline $\mathrm{Fe}$ & $\mathrm{Y}=126.64 \mathrm{x}+7214.6$ & $0.50 \%$ & 0.071 & 3490.3 & 3.543 \\
\hline $\mathrm{Ni}$ & $\mathrm{Y}=-19.054 \mathrm{x}+51.52$ & $0.23 \%$ & 0.048 & 319.14 & 2.504 \\
\hline $\mathrm{Cu}$ & $\mathrm{Y}=-26.966 \mathrm{x}+74.41$ & $1.70 \%$ & 0.130 & 149.53 & 2.175 \\
\hline $\mathrm{Zn}$ & $\mathrm{Y}=71.056 \mathrm{x}+43.602$ & $11.60 \%$ & 0.341 & 157.61 & 2.196 \\
\hline
\end{tabular}

Table 3. Pearson product moment correlation coefficients between metal levels in the media

\begin{tabular}{|c|c|c|}
\hline Metal pairs & Sediments & Surface water \\
\hline $\mathrm{Cd}-\mathrm{Pb}$ & $0.602 * *$ & - \\
\hline $\mathrm{Fe}-\mathrm{Cd}$ & $-0.485^{*}$ & - \\
\hline $\mathrm{Ni}-\mathrm{Cd}$ & $0.702 * *$ & - \\
\hline $\mathrm{Cu}-\mathrm{Cd}$ & $0.515^{*}$ & - \\
\hline $\mathrm{Zn}-\mathrm{Cd}$ & $0.568 * *$ & $0.601 * *$ \\
\hline $\mathrm{Ni}-\mathrm{Pb}$ & $0.478^{*}$ & - \\
\hline $\mathrm{Cu}-\mathrm{V}$ & $-0.450 *$ & - \\
\hline $\mathrm{Zn}-\mathrm{V}$ & $-0.448^{*}$ & - \\
\hline $\mathrm{Ni}-\mathrm{Fe}$ & $-0.572 * *$ & - \\
\hline
\end{tabular}


Ibigoni Clinton Howard and Briggs Amonia Olulu / Our Nature (2012) 10: 206-216

\begin{tabular}{|c|c|c|}
\hline $\mathrm{Cu}-\mathrm{Fe}$ & $-0.550^{*}$ & $0.540^{*}$ \\
\hline $\mathrm{Zn}-\mathrm{Fe}$ & $-0.498^{*}$ & - \\
\hline $\mathrm{Cu}-\mathrm{Ni}$ & $0.847^{* *}$ & - \\
\hline $\mathrm{Zn}-\mathrm{Ni}$ & $0.873^{* *}$ & - \\
\hline $\mathrm{Zn}-\mathrm{Cu}$ & $0.921^{* *}$ & $0.582^{* *}$ \\
\hline $\mathrm{Fe}-\mathrm{Pb}$ & - & $0.583^{* *}$ \\
\hline $\mathrm{Cu}-\mathrm{V}$ & - & $\mathrm{r}_{18}=0.561$ \\
** Correlation is significant at the 0.01 level $(\mathrm{n}=20)$ and $\mathrm{r}_{18}$ & and $\mathrm{r}_{18}=0.444$ \\
\hline
\end{tabular}

from the lower and upper reaches of the river, similarity in physical conditions of the sediments, particle composition and organic matter of the sediments between the stations. The MPI of the surface water in stations B (Abonnema) and D (Idama flow station) was higher than that of the other stations while that of the sediments, stations A (Agada) and B (Abonnema) are higher than the other stations, although these difference were not significant. The high MPI in these stations could be due to domestic surface water runoff, Inland surface water runoff, waste water discharges, etc. Station A (Agada) has been noted earlier to be the receiving end of the Orashi River which houses a lot of crude oil industrial activities and the washings thereof empties into this station. The domestic runoff discharges and other farming activities from the adjourning lands also add to the sediment pollutant load of the station.

Cd levels obtained in this study in both media are higher than that reported by Masoud et al. (2005) in Lake Edku, Egypt, but similar to that reported by Okafor and Opuene (2007) from Taylor creek in the Niger Delta. Although Cd presented a low level in this study (when compared to similar studies in the region), it is very toxic to both aquatic and terrestrial organisms even at low concentrations. This is because dissolved $\mathrm{Cd}$ has acute $\mathrm{LC}_{50}$ values as low as $3.5 \mathrm{mg} / \mathrm{l}$ in planktonic organisms. In addition, $\mathrm{Cd}$ is a sulphur seeking metal that tends to precipitate in anoxic sediments. Experiments carried out at concentrations lower than the values found in this study also show that $\mathrm{Cd}$ can be assimilated from anoxic sediments with high organic matter content, which generates the potential for bioaccumulation through dietary uptake.

The levels of $\mathrm{Pb}$ in the sediments were low when compared with $\mathrm{Pb}$ levels in the sediments of Taylor creek (Okafor and Opuene, 2007) and Antarctic sediments, but are higher than the sediments of Mombassa River, Kenya and Lake Edku, Egypt (Masoud et al., 2005). The present result indicates that the maximum values are recorded at stations $\mathrm{B}$ and $\mathrm{D}$, while the minimum was recorded at station $\mathrm{A}$ for surface water. Station A has the maximum value and station $\mathrm{D}$ the minimum for the sediments. The datum is of typical anthropogenic and urban activities (Maiti, 2003), and accumulation in plants and phytoplankton. Whether the levels found are a threat is dependent on a number of factors. For example, certain water chemistry parameters of the aquatic system, such as $\mathrm{pH}$ and oxygen levels, would control the rate of adsorption and desorption of $\mathrm{Pb}$ to and from the sediments. Lead in sediments is chemically precipitated from the surface water solution, and the remainder has been 
Ibigoni Clinton Howard and Briggs Amonia Olulu / Our Nature (2012) 10: 206-216

transported in detrital particles. However, lead occurring in sediments has two distinct mineral associations, one with the clay minerals and the other with authigenic minerals and/or biogenous debris. When released into the environment lead has a long residence time compared with most other pollutants. It has low solubility and does not experience microbial degradation. For these two reasons, $\mathrm{Pb}$ has the potential to remain accessible within the sediments and consequently, aquatic food chains far into the future (Davies et al., 1991).

Levels of $\mathrm{Fe}$ of the lower reaches of Sombriero river surface sediments and water exceeded those for the Taylor creek in the Niger Delta (Okafor and Opuene, 2007), Antartic aquatic ecosystem (Andrade et al., 2001) and Lake Edku, Egypt (Masoud et al., 2005). This high levels of Fe especially in the sediments of this study could be due to high level of dissolved oxygen and $\mathrm{pH}$ that leads to precipitation of $\mathrm{Fe}(\mathrm{OH})_{3}$. High concentration of oxygen leads to iron oxidation and subsequent hydrolysis to form insoluble $\mathrm{Fe}(\mathrm{OH})_{3}$ according to the following reactions: (Masoud et al., 2005)

$$
\begin{aligned}
& 2 \mathrm{Fe}^{2+}+{ }_{1} / 2 \mathrm{O}_{2} \rightleftharpoons \mathrm{H}^{+} \\
& \mathrm{Fe}^{3+}+3 \mathrm{He}_{2} \mathrm{O} \rightleftharpoons \mathrm{Fe}(\mathrm{OH})_{3}+3 \mathrm{H}_{2} \mathrm{O}
\end{aligned}
$$

Apart from this the removal of iron and other trace elements from water systems by planktonic organisms may also take place through: 1) assimilation by organisms and subsequent transport as fecal material, and 2) body adsorption (Brewer, 1975).

For $\mathrm{Zn}$ metal, the highest levels were found at stations $\mathrm{A}$ and $\mathrm{B}$, thus relating the likely source of this pollutant to surface water runoffs, waste water and domestic discharges. $\mathrm{Zn}$ correlated with $\mathrm{Cd}$ in both surface water and the sediments indicating that both metals could be from the same sources and their partitioning between the two media could also be of the same mechanism. It is also noteworthy that $\mathrm{Zn}$ is an essential trace element for both flora and fauna and exposure to either deficient or high levels can have deleterious effects on an organism's health. It exists in sea water in submicromolar concentrations (Vasanti and Pillai, 1975). It has been reported that organic complexation controls the concentration of dissolved zinc in aquatic environment (Van Den Berg et al., 1987). Zinc is essential for growth of marine organisms and its concentration affected by plankton communities (Masoud et al., 2005). The kinetics of removal of Zinc in aquatic systems is strongly affected by the rates of biological processes. It is also a common pollutant found in several industrial effluents such as those produced by textile, basic chemicals, electroplating, motor and other industries. The level of $\mathrm{Zn}$ recorded in this study were higher than that reported in similar study in both surface water and sediment (Howard et al., 2006, but lower than that of the Antartic aquatic ecosystem (Andrade et al., 2001) and the $\mathrm{H}^{+}$Taylor Creek (Okafor and Opuene, 2007).

The levels of $\mathrm{Ni}$ also showed a consistent distribution in the study area. The natural sources of this element are ferromanganese minerals and ferrous sulfides. Nickel may be present in some ground waters as a consequence of dissolution from nickel ore-bearing rocks. Nickel is used principally in its metallic form combined with other metals and nonmetals as alloys. This is corroborated by the significant correlation of $\mathrm{Ni}$ with $\mathrm{Fe}$, and other metals such as $\mathrm{Cu}, \mathrm{Cd}$ and $\mathrm{Zn}$. 
Ibigoni Clinton Howard and Briggs Amonia Olulu / Our Nature (2012) 10: 206-216

Average $\mathrm{Ni}$ concentrations are $94 \mathrm{mg} / \mathrm{g}$ in igneous rocks and between 2.6 and 29 for different types of sedimentary rocks. The levels of $\mathrm{Ni}$ obtained were higher than the reported values for sediments in the Taylor creek (Okafor and Opuene, 2007) and Lake Edku, Egypt (Masoud et al., 2005) but lower than those of the Marina area of Great Athens.

The level of $\mathrm{Cu}$ recorded in this study were higher than that reported in a similar study in both media ; they are however lower than that reported by Aboud et al. (2009) in the sediments of Bangalore Urban lakes and Lake Edku, Egypt (Masoud et al., 2005). $\mathrm{Cu}$ correlated positively with $\mathrm{Fe}$ in both media signifying that the input sources into the river system might be the same and also both metals gets partitioned between both media the same way. Copper precipitation is influenced by biological and geological processes (Hasle and Abdullah, 1981). The data could be speculated that the source of the dissolved copper in water may be outlined to remobilization from sediments. However such approach could be subjected to further steps, mainly of adsorption and coprecipitation phenomenon of dissolved species on to suspended matter (Masoud et al., 2005).

Vanadium levels in the sediments of the study area are lower than that reported by (EL-Moselhy, 2006) in the Marine coastal area of Egyptian seas, Mediterranean Sea and also below the range of typical background values $(20-150 \mathrm{~g} / \mathrm{g}$ ) that was recorded by Moore (1991). Vanadium levels in the surface waters of the study area are comparable to that obtained from Sea water and the Baltic sea (Soremark, 1967). Vanadium is a ubiquitous element in the earth's crust, and exist in divers' forms but the pentavalent form is the most soluble, and is the primary agent of transport in surface water (Moore, 1991). Breslin and Duedall (1988) and FAO (1992) have stated earlier that the main source of vanadium is the petroleum activities and fuel burn. This is corroborated by the fact that Station D which is the Idama flow station had the highest $\mathrm{V}$ value of this study. Other significant sources include the dumping of sewage sludge, discharge of domestic wastewater and the industrial effluents specially fertilizers containing materials with high vanadium content. Vanadium is also solublized from stabilized oil ash waste in seawater (Breslin and Duedall, 1988).

\section{Conclusion}

The data obtained in this study has showed consistency in the metal pollution indices of the various stations of the study area. This may be due to the continuous dilution of the water body from the lower and upper reaches of the river, similarity of the physical conditions of the sediments, particle composition and organic matter of the sediments may have also played major role. The stations with higher pollution indices are related to areas of intense activities such as the Idama flow station and Abonnema for the surface water and Agada and Abonnema for the sediments. Several metal pair correlations were obtained in the surface sediments than in the surface water. Both media had $\mathrm{Zn}-\mathrm{Cd}$ and $\mathrm{Cu}-\mathrm{Fe}$ metal pair correlations. The pattern of the metals in the surface water at $95 \%$ significant level is $\mathrm{Fe}>\mathrm{Zn}=\mathrm{Cu}=\mathrm{Pb}=\mathrm{N}=\mathrm{Cd}=\mathrm{V}$ while that of the sediment is $\mathrm{Fe}>\mathrm{Zn}=\mathrm{Cu}=\mathrm{Ni}=\mathrm{Pb}=\mathrm{V}=\mathrm{Cd}$. This study revealed that the sediment from the upper reaches of Sombriero river contained very high significant amounts of heavy metals when compared with their 
Ibigoni Clinton Howard and Briggs Amonia Olulu / Our Nature (2012) 10: 206-216

concentration in water. In comparison to other related work the degree of contamination of the upper reaches of the Sombriero River is low but a gradual enrichment of these pollutants could have a deleterious effect on the aquatic resources of the area and the consumers thereof.

\section{Acknowledgements}

The authors wish to thank the staff and management of Institute of Pollution Studies Laboratory, Rivers State University of Science and Technology, Port Harcourt Rivers State and Water Well Services laboratory Effurun Delta State, Nigeria where the analyses were carried out.

\section{References}

Aboud, S. Jumbe and N. Nandini 2009. Heavy metals analysis and sediment quality values in urban lakes. American Journal of Environmental Sciences 5(6): 678-687.

Adams, T.G., G.T. Atchison and R.T. Velter 1980. The impact of an industrially contaminated lake on heavy metal levels in its effluent stream. Hydrobiologia 69(1-2): 187-193.

Agah, H., M. Leermakers, M. Elskens, S.M.R. Fatemi and W. Baeyens 2009. Accumulation of trace metals in the muscles and liver tissues of five fish species from the Persian Gulf. Environ. Monit. Assess. 157: 499-514.

Agirtas, M.S. and F. Kilice 1999. Determination of $\mathrm{Cu}, \mathrm{Ni}, \mathrm{Mn}$ and $\mathrm{Zn}$ pollution in soil at the shore of Van Lake with Flame Atomic Spectrophotmetry. Bulletin of Pure and Applied Science 18: 45-47.

Andrade, S., A. Poblet, M. Scagliola, C. Vodopivez, A. Curtosi, A. Pucci and J. Marcovecchio 2001. Distribution of heavy metals in surface sediments from an Antartic marine ecosystem. Environ. Monitor. Assess. 66: 147-158.

APHA 1995. Standard methods for the examination of water and wastewater. $19^{\text {th }}$ Ed., American Public Health Association. Review.

Biney, C.A., D. Calamari, H. Naeve, T.W. Maembe, B. Nyakageni and M.A.H. Saad 1994. Scientific basis for pollution control FAO (CIFA). Technical paper 25: 7-20.
Breslin, V.T. and I.W. Duedall 1988. Vanadium release from stabilized oil ash waste in seawater. Environ. Sci. and Technol. 22: 1166-1170.

Brewer, P.G. 1975. Minor elements in seawater. In Chemical Oceanography, $2^{\text {nd }}$ Ed. (Eds. J.P. Riley and G.S. Hirrow). Academic Press, London. 1: 415-491.

Davies, C.A., K. Tomlinson and T. Stephenson 1991. Heavy metals in River Tees estuary sediments. Environ.Technol. 12: 961-972.

EL-Moselhy, K.H.M. 2006. Distribution of vanadium in bottom sediments from the marine coastal area of the Egyptian seas. Egyptian Journal of Aquatic Research 32(1): 12-21.

FAO 1992. Committee for inland fisheries of Africa. Report of the $3^{\text {rd }}$ session of the working party on pollution and fisheries. FAO Fisheries report. No. 471.

Forstner, U. and G.T.W. Wittmann 1983. Metal pollution in the aquatic environment. SpringVerlag Berlin Heidelberg New York. 486p.

Goodwin, T.H., A.R. Young, M.G.R. Holmes, G.H. Old, N. Hewitt, G.J.L. Leeks, J.C. Packman and B.P.G. Smith 2003. The temporal and spatial variability of sediment transport and yields within the Bradford Beck catchment, West Yorkshire. The Science of The Total Environment. 314316(1): 475-494.

Gupta, A., D.K. Rai, R.S. Pandey and B. Sharma 2009. Analysis of some heavy metals in the riverine water, sediments and fish from river Ganges at Allahabad. Environ. Monit. Assess. 157: 449-458.

Hasle, J.R. and M.I. Abdullah 1981. Analytical fractionation of dissolve copper, lead and cadmium in coast waters, Mar. Chem. 10: $487-$ 503.

Jackson, T.A. 1998. In Environmental Interactions of Clays (Eds. A. Parker and J.E. Rae) Springer: Berlin 93-205.

Maiti, S.K. 2003. Handbook of methods in environmental studies, Vol. 2. Air, noise, soil and overburden analysis. ABD Publishers.

Martine, J.M. and M. Whitfield 1983. The significance of river input of chemical elements to the Ocean. In Trace metals in seawater (Eds. K.W. Bruland, J.D. Burton and E.D. Goldberg). Plenum, New York. pp. 265-259

Masoud, M.A., A.E.S. Elewa, A.E. Ali and E.A Mohamed 2005. Distribution of some metal concentrations in water and sediments of lake 
Ibigoni Clinton Howard and Briggs Amonia Olulu / Our Nature (2012) 10: 206-216

Edku, Egypt. Bulletin of the Chemists and Technologists of Macedonia 24(1): 21-34.

Moore, J.W. 1991. Inorganic contaminants of surface water: research and monitoring priorities. Springer-Verlag, New York Inc. 334p.

Okafor, E.C. and K. Opuene 2007. Preliminary assessment of trace metals and polycyclic aromatic hydrocarbons in the sediments. Int. J. Environ. Sci. Tech. 4(2): 233-240.

Shukla, R. and Y.K. Sharma 2009. Heavy metal toxicity in environment. In Environmental monitoring and management (Eds. A. Trivedi, K. Jaiswal, B.N. Pandey and S.P. Trivedi). Alfa Publications. pp. 137-162.

Soremark, R. 1967. Vanadium in some biological specimens. The Journal of Nutrition 92: 182-190. Stanton, R.C., E.A. Lord, E.M. Engelbrecht and J.A.
Delport 1983. Toxic metals. In Detailed Report, Sludge disposal to sea. City Engineers's Department, Durban. pp. 77-101.

Van Den Berg, C.M., A.G. Merks and E.K. Duursma 1987. Organic complexation and control of the dissolved concentrations of copper and zinc in the Sheldt estuary. Est. Coast. Shelf Sci. 24: 785-797.

Vasanti, M. and K.C. Pillai 1975. Zinc in an estuarine environment. J. Mar. Biol. Assoc. India 17(2): 108-115.

Wahua, T.A.T. 1999. Applied statistics for scientific studies. Afrika-Link Books. Aba, Nigeria. pp. 129-249.

Weis, D.A., A.B. Calaway and R.M. Gersberg 1992. Vertical accretion rates and heavy metals chronologies in wet land sediments of the Tijuana Estuary. Estuaries 24(6A): 840-850. 